\title{
Discussion on "可愛い" culture and its market
}

\author{
Ping Zhao
}

School of Foreign Languages, Dalian Jiaotong University, Dalian, 116028, China

Keywords: “可愛い”culture; life; “可愛い” items,;marketization

\begin{abstract}
In the last few years, the phrase “可愛い” is widely used to describe people, objects and other things. On the contract, Chinese phrase "可爱” doesn't contain so many meanings as that in Japanese. Under the influence of "可愛い” culture, “可愛い” items, have won great popularity in Japan and even over the world. Why does such a phenomenon exist, and what is the reason, are the questions that should be required into. The thesis discussed the meanings of "kawaii" in Japanese, its subtle distinction with the Chinese word “可爱” , the background under which the “可愛い” culture is used, and the marketization of this culture. And the role the “可愛い” culture has played in influencing and promoting marketization in China is also introduced here.
\end{abstract}

\section{Introduction}

In Chinese vocabulary system, the new word "kawaii" is a foreign word, and it is transliterated from the Japanese word “可愛い”(cute or lovely in English). It is always translated as “lovely”. However, the two words are really the same with respect to lexical meaning. On this basis, an introduction is made in this paper to differences of both words in usage, followed by an introduction to Japan's “「可愛い」” culture and its marketization. Then, its influence and function on Chinese

\section{Differences between Japan and China in comprehension}

At present, the Japanese word “可愛い” can be freely translated as “可爱” in Chinese. Both words are adjectives with the meaning of "pleasing”. Besides, both words can be used to refer to animate people or animals as well as lifeless objects. Although the two words share similarities in terms of lexical meaning and usage occasion, they also have small delicate differences.

1. Animate objects

With the respect to its meaning of animate people or animals, both words have no difference, but their scopes are different. For instance:

(1)可愛い彼女 (a lovely girlfriend);

(2)可愛い猫 (a cute cat);

(3)可愛い男の子 (a lovely boy?);

(4)可愛いおばあちゃん (a lovely grandpa?)

In Chinese, both "girlfriend” and "cat” can be described as cute or lovely. For the example of (3), it is acceptable in Japanese, but it is strange in Chinese. The word "boy" should be used according to specific age of the person. In Japanese, this word is used to describe a handsome boy with a cartoon face. In Chinese, however, the word "handsome" is usually used, similar to the Japanese word “「かっこういい」”. Besides, age is also limited to a very small scope. If you praise a student in senior high school or ever elder than the said student as "cute or lovely", you will not get expected response, and the student may be disgusted with you at the same time. The example of (4) is generally used to describe good temper. A relatively easy-going grandpa here contains a sort of good temper here instead of cute appearance as a beautiful young girl. In Chinese, however, occasions to describe good temper or easygoing character are directly expressed as good temper in most cases. It is impolite to describe a grandpa or a grandma as "cute or lovely" under strange or unfamiliar circumstances.

\section{Lifeless objects}

When the word is used to describe lifeless objects: 
(5)可愛い入れ物 (an interesting small box);

(6)可愛い拼当 (a delicate rice box);

(7)可愛いサンダル (beautiful sandals)

The same as examples of (5)(6), the words "interesting”, “delicate”, "small” and "beautiful” are more appropriate, although it can be also described as "cute or lovely" in Chinese. Sometimes, the word is also used to indicate lifeless objects such as toy. However, the speaker also psychologically thinks that an object described as "cute or lovely" contains the semanteme of "animate", such as "cute Barbie doll” and "lovely hairy bear". Seemingly, this is similar to the usage of “「可愛い玩具」” (cute toy) in Japanese.

Apparently, the use scope of “可爱” (cute or lovely in English) is relatively small in China. Although it doesn’t reject the meaning of “childishness”, it can not cover connotation of “「可愛 い」”. In Japan, however, “「可愛い」” already reaches the degree of being used almost at all occasions. Despite of sex and age among Japanese people, “「可愛い」” already becomes a kind of mainstream aesthetic value. It seems that they give life and emotional basis to all people, animals, plants and even cold technological products. It also proves more the importance of “「可愛い」” culture in Japanese culture.

\section{Causes for Popularity of Japan’s “「可愛い」”Culture}

\section{Influence of traditional culture}

In traditional Japanese culture, the aesthetic conception of "small is beautiful" exists all the time. (1) In Genji Monogatari, The Pillow Book, and other Japanese books about classical literature, the feeling of "small is beautiful" is represented everywhere. It is described in The Pillow Book written by Sei Shonagon, a famous woman writer in the Heian Era that "beautiful things are: the little face on muskmelon, a sparrow's jump with chirps while listening to people's words......little kids in two or three years old crawl up in a hurry, subtly finding tiny dust on the road and rubbing soil with their small hands and showing to their parents, very lovely".

\section{Influence of modern social environment}

Firstly, Japanese women like to be surrounded by lovely objects, and they are eager for becoming cute. This is closely associated with the concept of "women are inferior to men" still existing in the current society. Lovely women are always looked delicate and helpless. Beside fragile women, men's heroic spirits will arise spontaneously, thus setting off by contrast men's predominance in a clearer way. As a result, this makes the “「可愛い」” culture to occupy a stable position among Japanese adults. Secondly, there are many social rules in Japan. Leader-member relations are strict. Usually, people feel high pressure and heavy responsibility. Hence, some adults unconsciously accept the lovely style. In their sub-consciousness, they would rather continue to be a child when compared with growing to be an adult. Although these people are physiologically adults, they fail to get enough development inwardly. On the one hand, they desire for care and love and want to be away from pressure. On the other hand, they are afraid of maturity and growth. Their cultural values, aesthetic standards and consumption views represent a sort of childish tendency. Considerate vogue rapidly grasps this consumption characteristic, providing this crowd of people with young, cartoon, lovely and even childish atmosphere and consumption, so as to remit their stress as adults in the society. The occurrence of these "lovely commodities" and consumption atmosphere provide huge space and motive for the marketization of “「可愛い」” culture.

\section{Marketization of “「可愛い」” Culture}

Modern Japanese young people's affection to the atmosphere of "lovely culture" certainly will give rise to plenty of lovely commodities. Small, exquisite and mellow Japanese cars are chased after and praised by many people. As an important pillar of Japanese economy, Japan's cartoon industry increased by 300\% between 1992 and 2002, and it becomes the largest export industry in 
Japan. With respect to cartoon images, Hello Kitty is the most successful case. This little cat without a mouth brings about revenues worthy of one billion dollars to the developer Sanrioco, Ltd every year. Similarly, Pikachu has already created sales performance of three trillion yens in the world. Moreover, photo booth photographic equipment was immediately popular in the world once it was published. Up to now, such photographic equipment can be seen in shopping malls and on pedestrian streets almost in all cities. Contemporary Japanese artists Takashi Murakami, Nara Yoshitomo and Yayoi Kusama promoted cartoon drawings to the whole world. The limited edition of LV luggage produced under cooperation of LV and Takashi Murakami ever caused extensive attention. The "concise" and "relaxed" concept brought by the lovely cartoon image is accepted by more people. The virtual female entertainer software "Hatsune Miku" developed by Crypton Company is popular in the entire world at present. Under high-tech 3D virtual image technology, she launched a solo concert. Unexpectedly, the concert is synchronically watched by 200,000 people in the world. So far, "Hatsune Miku" already drives commercial consumption opportunities worthy of 10 billion yens. Besides economic and cultural respects, the Japanese government is also good at utilizing the “「可愛い」” culture for external exchange in politics, becoming a sort of lubricant creating appetency. On March 12, 2009, Japanese Foreign Ministry elected three beautiful young girls in 18-19 years old as "lovely ambassadors". They promote Japanese culture to the world. The three girls are employed to increase soft strength of Japan and maintain the influence of Japan in the world.

\section{Influence of “「可愛い」” Culture on Chinese Market}

Since the reform and opening up in China, lagged traditional cultural education results in the deficiency of traditional culture for the crowds in the 1980s. Nowadays, China is an economic giant, but its culture industry exportation is still leveled as a small cultural country. This is extremely inconsistent with China's international position. Therefore, it is of great importance for cultural inheritance and international influence to forge the "lovely culture" with Chinese characteristics.

From the cartoon at full blast Pleasant Goat and Big Big Wolf to the hot variety show Where are we going? Dad, the trace of "lovely culture" can be found everywhere. Accordingly, the cartoon and the variety show also bring about fascinating economic benefits. Lovely images in Pleasant Goat and Big Big Wolf are accepted by the market and audiences. Bright color processing, humorous plot setting and integration of fashionable elements contribute to its success. After the first season of Where are we going? Dad is broadcasted, many relevant elements and products instantly become popular. Merchants successively promote their products with the "dad marketing wind". Auto enterprises, real estate developers, tourism agencies and garment manufacturers all participate into this "wind". The "dad concept" is found in a heap of varied companies as well as children products, scenic spots, autos, houses and video websites. By virtue of Where are we going? Dad, shooting locations of this show are made to become hot tourist attractions. The movie edition of Where are we going? Dad is also deemed as an amazing money maker of New Year movies in the film industry. On the bidding meeting of the second season, a merchant won the exclusive naming right of "Dad" with sponsorship fees of approximately 0.312 billion yuan. Certainly, all this is just the beginning of this vigorous momentum.

\section{Conclusion}

In conclusion, Japan and China have different understandings of “「可愛い」” and “可爱” (cute or lovely in English). However, both bring about economic effects to each country accordingly. Japanese “「可愛い」” culture has already become the token of Japan. However, some people doubt for this and think that it is to escape cruel reality and served as manifestation of playful spirit. If we can take advantage of “可爱” (cute or lovely in English) and get rid of its disadvantages, I believe that the “「可愛い」” culture will get development and continuous development in Chinese market. 


\section{References:}

[1] Ye Kai, From Kawaii Culture to “Lovely” Economy 【J】, Modern Literary Magazine, 2012-11-05;

[2] Guo Fuliang and Zhao Yanping, New Network Word “Kawaii” 【J】 , Chinese Construction, 2013-07-21;

[3] Zhang Yanping, Discussion on Japanese Lovely Culture 【J】, Success (Education), 2012-06-08;

[4] Wang Mi’na, Discussion on Japanese “Lovely Culture” Phenomenon and Its Social Influence

【J】 , Examination Weekly, 2010-05-14;

[5] Liu Bohong, Enlightenment of Japanese "Lovely Culture" on China's Animation Development 【J】, Southeast Communication, 2012-09-20;

[6] Chen Jing, Japan's “Lovely Culture” 【J】 , The Knowledge of Japanese, 2007-11-10;

[7] Sun Hua, Exploration for Lovely Culture in Variety Shows - with “Where Are We Going? Dad” as An Example 【J】, News, 2014-04-1;

[8] The author: Inuhiko Yomota; the translator: Sun Mengmeng, Discussion on Loveliness [M], Shandong People's Publishing House, 2011;

[9] Soichi Masubuchi，かわいい Syndrome [M], NHK, 1994;

[10] Takamasa Sakurai, World カワイイ Revolution [M], PHP New Book, 2009;

[11] Morinosuke Kawaguchi, Japanese Creativity - Lovely Economy [M], Business Weekly (Taiwan), 2009;

[12] Li Yuning, Japanese Shrinking Consciousness [M], Shandong People’s Publishing House, 2003 